\title{
Role of Budgeting in Modern Corporate Governance (Empirical Study in the Czech Republic) $)^{\#}$
}

\author{
Jana FIBÍROVÁ* - Libuše ŠOLJAKOVÁ**
}

\section{Introduction}

Budgets are one of the most widely used tools for planning and controlling organizations. But during the last ten years or so attitudes that companies should go "beyond budgeting" and abandon budgeting in practice have been presented by experts in both literature and in discussion meetings. The aim of the research was to discover whether budgeting is able to support and improve the Corporate Governance and whether companies have changed their budgeting practices in recent years. The research was conducted in two phases with a questionnaire survey and direct interviews with managers.

\section{Literature review}

It was implicitly assumed that budgets serve as an important managerial need and textbooks such as Drury (2007), Král (2006), Fibírová and Šoljaková (2005), Fibírová, Šoljaková and Wagner (2007) rehearse the importance of budgets in: planning, co-ordinating, communicating, motivating, controlling and evaluating operations; Horngren, Datar and Foster (2006): "Budgets are a major feature of most management control systems, they can compel planning including the implementation of plans, provide performance criteria, promote

\# This paper was prepared in the framework of research plan Development of Accounting and Financial Theory and its Application in Practice from Interdisciplinary Point of View (registered number MSM 6138439903).

Prof. Ing. Jana Fibírová, CSc. - professor; Department of Managerial Accounting, Faculty of Finance and Accounting, University of Economics, Prague, W. Churchill Sq. 4, 13067 Prague 3, Czech Republic; <fibirova@vse.cz>.

** Doc. Ing. Libuše Šoljaková, Ph.D. - associate professor; Department of Managerial Accounting, Faculty of Finance and Accounting, University of Economics, Prague, W. Churchill Sq. 4, 13067 Prague 3, Czech Republic; <soljak@vse.cz>. 
communication and coordination within organization, affect behavior and organizational processes". The researchers wished to establish the conditions in which different forms of budgeting were appropriate, not to challenge the usefulness of budgeting itself (Lorino (1996), Kaplan and Norton (1996), Eschenbach (2000). However, this changed in the 1990s as Hope and Fraser (2003) mounted a wide-ranging critique of the manner in which budgeting systems are typically implemented. They have observed and described budgeting systems highlighting "the often bureaucratic and expensive nature of the budgeting process, the failure of budgeting to meet the needs of managers in uncertain and competitive environments and the likelihood that budget systems would lead to managerial "gaming" of the numbers."

\section{Methodology}

The research is based on direct investigation of the actual situation in the Czech Republic. The questionnaire was developed and then sent to 350 random screens of industrial and commercial companies in the Czech Republic. Seventy-two responses are included in this research. The companies included in the research operate in various areas of business (see Figure 1). Then several top managers (Chief Executive Officers and Chief Financial Officers) were interviewed directly. The analyses are based on basic statistical methods.

\section{Hypothesis}

The empirical research assured the following main hypothesis:

A. The application of budgets has changed in recent years.

B. According to managers budgets are able to support and improve corporate governance. The attitudes of financial and non-financial managers toward budgets differ.

C. Methods of preparing budgets and budgetary control as well as the relation of budgets to incentives have an influence on corporate governance. 


\section{Hypothesis A}

\section{The application of budgets has changed in recent years.}

According to the empirical research most companies (52\%) consider budgets as a traditional significant tool useful for decision making and control. Budgets have to be continually improved in order to adapt to changes in the business environment and to encourage the successful development of companies.

$11 \%$ of companies use budgets in a traditional manner but budgets are only a formal tool required, for example, by banks, financial institutions, and owners. They are not used as active management tools. The reasons could be:

- management has no interest; they prefer intuitive and interactive management methods;

- the business activity is fixed and developed continually;

- the business activity is too variable to predict using budgets.

Only $5 \%$ of the companies have eliminated or reduced the application of budgets in recent years because:

- budgets do not encourage the business development and performance.

- budgets are only bureaucratic and administratively complicated tools; expenses regarding budget preparation and control have been higher than the benefit obtained from budgets.

- the budgets were only a formal tool.

$32 \%$ of companies have intensified application of budgets in recent years and this change was evoked by:

- the owner in connection with a change of ownership (25\%);

- managers in connection with the development of companies $(44 \%)$;

- new managers in connection with their arrival in the post (31\%).

Budgeting practice has changed in recent years but, according to this research, little of it was driven by the "beyond budgeting" movement. 
Fibírová, J. - Šoljaková, L.: Role of Budgeting in Modern Corporate Governance (Empirical Study in the Czech Republic).

Instead there has been an intensification of the budgeting processes application. (See figure 3)

\section{Fig. 1: Changes in budgeting}

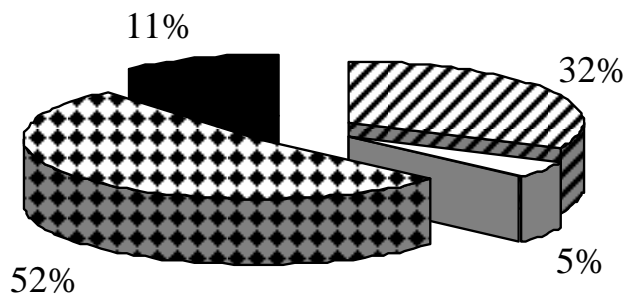

$\boldsymbol{\nabla}$ yes, we improved the budgets system to encourage the planning and control,

$\square$ yes, we eliminate the budgets as management tool, they had no contribution to development of company

$\boldsymbol{\nabla}$ no, budgets are traditional significant tool necessary for planning and control

no, budgets are only formal tool and management is not interested in it

The correlation between business development and budget application confirms:

- the dynamically developing companies and more developed companies consider budgets more significant and use budgets more intensively. These companies also permanently try to improve budgeting systems;

- the companies with constant business development used budgets but they have no interest in improving and developing their budgeting system;

- the companies that eliminate their business activities could not be analyzed due to the small number of such respondents (only 3 companies). 


\section{Hypothesis B}

According to managers budgets are able to support and improve corporate governance. The attitudes of financial and non-financial managers toward budgets differ.

The following alternatives of budget consideration were tested for the purpose of proving this hypothesis:

- Budgets are only bureaucratic and administratively complicated tools. They have negative influence on corporate governance, because they limit and formally measure business activities of the companies and their business units without any careful analyses of the actual conditions and development possibilities. Budgets also support irrational manager behavior in order to meet the budgets. They, for example, move the sales or cost on purpose from period to period.

- Budgets represent an important management control tool supporting and improving corporate governance. They serve a number of useful purposes:

- coordinating and communicating the activities of various parts of the organization and ensuring that the parts are in harmony with each other;

- motivating managers to strive to achieve the goals set;

- controlling activities.

- Budgets provide important information for decision making, for setting standards, costs, margin, profit of products and customers. They contribute to product volume and structure optimizing and the increase of performance.

Managers were to use a scale from 1 to 5 to valuate their acceptance of the budget. ( 1 - absolute disapproval, 5 - absolute acceptance). The answers were analyzed in relation to financial and non-financial managers and in relation to the level of power and responsibility. Tab. 1 shows the average value according to the manager groups 
Fibírová, J. - Šoljaková, L.: Role of Budgeting in Modern Corporate Governance (Empirical Study in the Czech Republic).

Tab. 1: Budget consideration

\begin{tabular}{|c|c|c|c|c|}
\hline \multirow[b]{3}{*}{ Consideration } & \multirow{3}{*}{$\begin{array}{l}\text { Financial } \\
\text { managers }\end{array}$} & \multicolumn{3}{|c|}{ Non-financial managers } \\
\hline & & \multirow[b]{2}{*}{ top } & \multicolumn{2}{|c|}{ middle and lower } \\
\hline & & & $\begin{array}{l}\text { high level of } \\
\text { power and } \\
\text { responsibility }\end{array}$ & $\begin{array}{c}\text { low level of } \\
\text { power and } \\
\text { responsibility }\end{array}$ \\
\hline $\begin{array}{l}\text { Bureaucratic and } \\
\text { administratively } \\
\text { complicated tool }\end{array}$ & 1000 & 1316 & 1579 & 2316 \\
\hline $\begin{array}{l}\text { Important } \\
\text { management } \\
\text { control tool } \\
\text { supporting and } \\
\text { improving } \\
\text { corporate } \\
\text { governance }\end{array}$ & 3539 & 3342 & 2000 & 1158 \\
\hline $\begin{array}{l}\text { Important tool for } \\
\text { decision making }\end{array}$ & 3697 & 3482 & 1789 & 1211 \\
\hline
\end{tabular}

Outcomes show the positive budget consideration by all top managers - both financial and non-financial. Research did not confirm the different attitudes of financial and non-financial top managers toward budgets. In our opinion the relatively small variances in outcome for financial and non-financial managers' is more the result of the different priorities of managers than from attitudes toward budgets themselves. The decreasing level of power and responsibility means the low positive attitude toward budgets. Middle and lower level managers with a low level of power and responsibility consider budgets as a bureaucratic, non-flexible and administratively complicated tool that neither supports management control nor decision making.

Managers prefer the role of budgets in decision making to management control but the difference is not significant enough to make a distinct conclusion.

An analysis of budget consideration according to shareholder's structure confirms a relation of the shareholder's structure to their consideration of the budget. For example a negative attitude toward 
budgets has managers of companies that belong to foreign holding - see Tab. 2.

Tab. 2: Budget as bureaucratic and administratively complicated tool according to the shareholder's structure

\begin{tabular}{|l|r|r|r|r|}
\hline & & \multicolumn{3}{|c|}{ Non-financial managers } \\
\cline { 3 - 5 } Consideration & Financial & & \multicolumn{2}{|c|}{ middle and lower } \\
\cline { 4 - 6 } & managers & top & $\begin{array}{c}\text { high level of } \\
\text { power and } \\
\text { responsibility }\end{array}$ & $\begin{array}{c}\text { low level of } \\
\text { power and } \\
\text { responsibility }\end{array}$ \\
\hline Sole investors & 1000 & 1167 & 1000 & 1000 \\
\hline Domestic holding & 1000 & 1316 & 1737 & 1842 \\
\hline Foreign holding & 1000 & 1421 & 1842 & 2684 \\
\hline
\end{tabular}

Negative budget consideration by middle and lower level managers in foreign holding is caused above all by:

- the limited possibilities of these managers to take part in the budget process, managers take part in the first phases of budgeting process, but both higher level and board create and approve final budgets without coordination with responsible managers. Then the responsible managers do not accept the budgets as proper target,

- the incompatibility between company goals and the goals of these managers,

- the poor ability of top managers and board to explain all the circumstances and contexts of the budgets to each other and lower level of managers,

- the lower flexibility of management systems in multination holdings.

On the other hand the companies of sole investors are able to involve the middle and low-level managers in the process of budget preparation and budgetary control, to ensure easier communication and clearer contribution analysis.

The positive budget consideration in relation to shareholder's structure shows table 3 and 4. 
Fibírová, J. - Šoljaková, L.: Role of Budgeting in Modern Corporate Governance (Empirical Study in the Czech Republic).

Tab. 3: The budget as a management control tool according to the shareholder's structure

\begin{tabular}{|l|c|c|c|c|}
\hline \multirow{2}{*}{ Consideration } & \multirow{2}{*}{$\begin{array}{c}\text { Financial } \\
\text { managers }\end{array}$} & top & \multicolumn{3}{|c|}{$\begin{array}{c}\text { Non-financial managers } \\
\text { high level of } \\
\text { power and } \\
\text { responsibility }\end{array}$} & $\begin{array}{c}\text { low level of } \\
\text { power and } \\
\text { responsibility }\end{array}$ \\
\hline Sole investors & 3000 & 3000 & 3000 & 1667 \\
\hline Domestic holding & 3526 & 3105 & 1842 & 1211 \\
\hline Foreign holding & 3526 & 3316 & 2684 & 1000 \\
\hline
\end{tabular}

Tab. 4: The budget as a tool for decision making according to the shareholder's structure

\begin{tabular}{|l|c|c|c|c|}
\hline \multirow{2}{*}{ Consideration } & \multirow{2}{*}{$\begin{array}{c}\text { Financial } \\
\text { managers }\end{array}$} & \multirow{2}{*}{ top } & \multicolumn{3}{|c|}{\begin{tabular}{c} 
Non-financial managers \\
\cline { 3 - 5 }
\end{tabular}} & & $\begin{array}{c}\text { middle and lower } \\
\text { power and } \\
\text { responsibility }\end{array}$ & $\begin{array}{c}\text { low level of } \\
\text { power and } \\
\text { responsibility }\end{array}$ \\
\hline Sole investors & 3000 & 3667 & 3000 & 1667 \\
\hline Domestic holding & 3842 & 2789 & 1632 & 1105 \\
\hline Foreign holding & 3737 & 3737 & 2263 & 1421 \\
\hline
\end{tabular}

The positive budget consideration outcomes from (excepted traditional points):

- setting the goals for each level of management,

- supporting internal control system, they could prevent some frauds

- coordinating of activities 


\section{Hypothesis C}

Methods of preparing budgets and budgetary control as well as the relation of budgets to incentive scheme have an influence on budget consideration.

Managers should evaluate the influence of the following factors on budget consideration:

- methods of budgets preparing,

- manager participation in budgeting process,

- level of power and responsibility managers,

- relation to incentive scheme,

- personal features of managers.

The responses were scaled from 1 to 5 ( 1 - no significant, 5 - most significant). The figure 4 shows the average valuation.

Fig. 2: Budget consideration factors

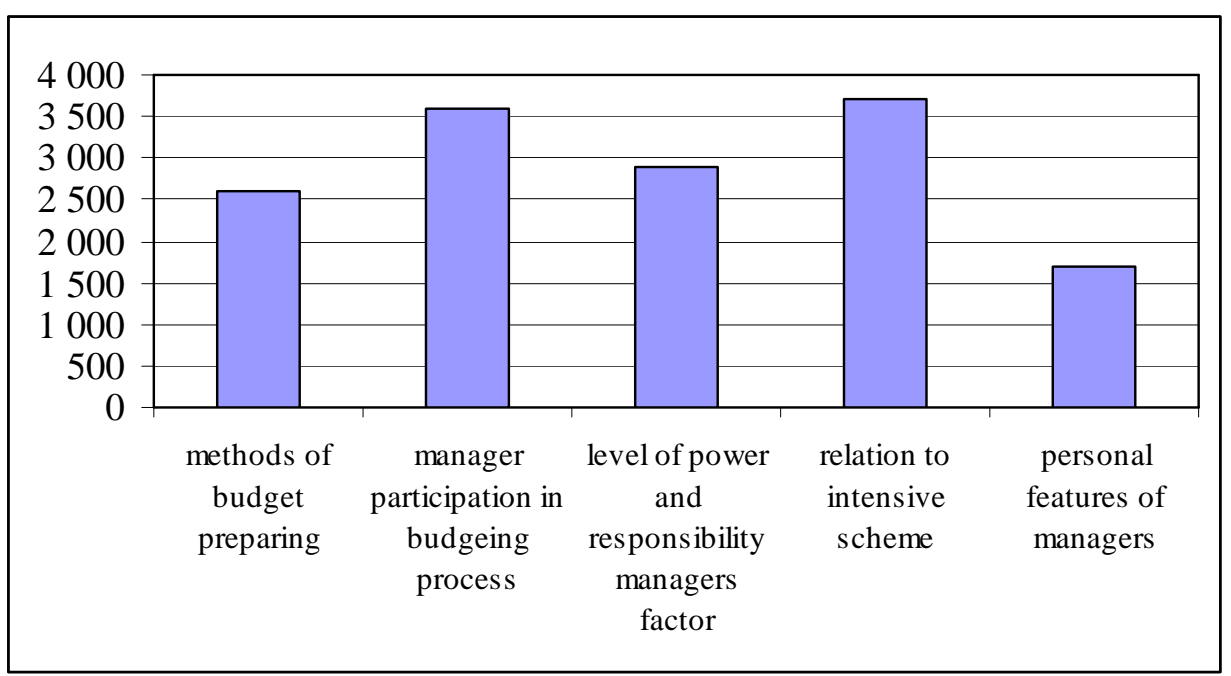

The relation to incentive scheme is the most important factor according to the study. This factor absolutely supports budget consideration as a tool for motivation and control. The managers addressed are consistent with the opinion that the budget is only a formal tool without closed relation to employee remuneration. On the other hand the positive variance from budget could not be the single measure. 
The second most important factor referring to the previous point is manager participation in the budgeting process. In the case that managers have the opportunity to take part in budget preparation and control and they accept the budget as a personal task, budget efficiency increases. If the budget is only a directive and managers do no accept them or they consider them as unmeetable, managers have no motivation to meet the budget goals.

This opinion supports the importance of the third factor - the level of manager power and responsibility.

The lower the importance was found in respect of methods of budget preparation. Most companies use traditional methods based on the actual outcome in the previous year adjusted by supposed changes in volume and structure of activities.

The personal characteristics of managers carry the least importance. The research does not confirm that today there is no possibility to control a lot of managers (above all the creative characteristic) through budgets or similar "hard" measures.

\section{Conclusions}

A survey of 72 companies investigated whether companies still use budgets, whether practice is changing and what the attitudes of financial and non-financial managers are towards budgets and its role in Corporate Governance.

Companies still use budgets, even intensifying their application over what is required, above all in connection with changes in ownership, managers in connection with the development of companies, new managers in connection with their arrival in post. The dynamically developing companies and more developed companies consider budgets more significant and use budgets more intensively. These companies also permanently try to improve budgeting systems.

The attitudes of top financial and non-financial managers toward budgets are broadly positive. The middle and low managers do not consider budgets as such an important tool. Negative consideration of budgets by middle and low level managers in multinational companies is caused above all by limited manager possibilities to take part in the budget 
process and the poor ability of top managers and owners to explain all circumstances and contexts of budgets.

The study indicated that managers continue to regard the budget processes as important and the "beyond budgeting" movement has had little impact on the surveyed companies. Changes have led to additional techniques or analytical detail rather than a reduction in traditional budgeting.

A relation to incentive scheme and manager participation in budgeting process is the most important factors according to the study. These factors absolutely support budget consideration as tool for motivation and control. On the other hand the personal features of managers are not very significant.

\section{References}

[1] Drury, C. (2007): Management \& Cost Accounting. London, Thomson, 2007.

[2] Eschenbach R. et al. (2000): Controlling. Praha, Codex, 2000.

[3] Fibírová J. - Šoljaková L. (2005): Hodnotové nástroje ř́izení a měrení výkonnosti podniku. Praha, ASPI, 2005.

[4] Fibírová J. - Šoljaková L. - Wagner, J. (2007): Nákladové a manažerské účetnictví. Praha, ASPI, 2007.

[5] Hope B. - Fraser R. (2003): Beyond Budgeting. Boston, Harvard Business School, 2003.

[6] Horngren, C. T. - Datar, S. M. - Foster, G. (2006): Cost Accounting: A Managerial Emphasis. Upper Saddle River, Prentice Hall; 2006.

[7] Kaplan, R. S. - Norton, D. P. (1996): The Balanced Scorecard: Translating Strategy into Action. Boston, Harvard Business School, 1996.

[8] Král, B. et al. (2006): Manažerské účetnictví. Praha, Management Press, 2006.

[9] Lorino P. (1996): Le contrôle de gestion stratégique. La gestion par les activités. Paris, Dunod, 1996. 


\title{
Role of Budgeting in Modern Corporate Governance (Empirical Study in the Czech Republic) \\ Jana FIBÍROVÁ - Libuše ŠOLJAKOVÁ
}

\begin{abstract}
The differing opinions of both experts and managers on the application of budgets in the dynamic changing business environment were inspiration for the empirical study that is oriented on the importance of budgets to performance management. The paper results from the empirical research. Analyses and conclusions presented in this paper cover the following issue:

The first part analyses changes in the application of budgets in recent years and the indicators of these changes.

The second part is oriented on the opinions of managers of budgets and explores whether managers consider budgets an important management tool supporting and improving Corporate Governance. Analyses concentrate also on differences between the attitudes of financial and nonfinancial managers and between middle level and top managers.

The last part of the project focuses on recognition of factors that have an influence on budget consideration such as methods of budget preparation, manager participation in budgeting process, level of power and responsibility managers, relation to incentive scheme, and the personal characteristics of managers.
\end{abstract}

Key words: Budgeting; Corporate Governance; Management Tools.

JEL classification: M41. 